INTERNATIONAL JOURNAL
PHARMACEUTICAL SCIENCES
RESEARCH
RESTI

Received on 19 August 2018; received in revised form, 20 May 2019; accepted, 30 May 2019; published 01 July 2019

\title{
IN-VITRO COMPARATIVE ANTICANCER ACTIVITY STUDY OF METHANOLIC EXTRACT OF TRADITIONALLY USED MEDICINAL PLANT OF MIZORAM
}

\author{
S. M. Abdul Aziz Barbhuiya and S. H. Victoria Devi *
}

Regional Institute of Paramedical and Nursing Sciences, Zemabawk, Aizwal - 796017, Mizoram, India.

Keywords:

Trypan blue test,

Cytotoxicity, Human cervical cancer cell (Hela cell), Anti-cancer

\section{Correspondence to Author:}

S. H. Victoria Devi

Assistant Professor,

Department of Pharmacy, Regional

Institute of Paramedical and Nursing

Sciences, Zemabawk, Aizwal -

796017, Mizoram, India.

E-mail: victoriadevi09@gmail.com

\begin{abstract}
Objective: The present study explores the anticancer potentially of plant sample based on the evidence from the ethnomedicinal practice of the plant. The main objective was to find out the in-vitro comparative anticancer activity of the various methanolic extract. Method: Plants samples such as Mikania micrantha, Allium hookeri, Eryngium foetidium, and Alpinea galanga were collected, identified, and authenticated. By using Trypan blue test Human cervical cancer (Hela), cells were counted. The Human cervical cancer (Hela) cells were treated with methanolic extract of Mikania micrantha, Allium hookeri, Eryngium foetidium, and Alpinia galangal and $20 \mu \mathrm{L}$ of MTT ( $5 \mathrm{mg} / \mathrm{mL})$ solution was added to cells per well, and the plate was moved to a $\mathrm{CO}_{2}$ incubator (3-4 $\mathrm{h}$ incubation). Measurement was performed using a Spectramax M2 Microplate Reader (Molecular Diagnostic, Inc.) at a wavelength of $570 \mathrm{~nm}$. Results: The Cytotoxicity of studied medicinal plants of Mizoram such as Mikania micrantha, Allium hookeri, Eryngium foetidium, and Alpinia galanga exhibited cytotoxicity in an increased manner with increase concentration against Hela cells. Their $\mathrm{IC}_{50}$ values were $49.02,138.5,199.7$, and $209.4 \mu \mathrm{g} \mathrm{mL}^{-1}$, respectively. The $\mathrm{IC}_{50}$ of doxorubicin was found to be $3.305 \mu \mathrm{g} \mathrm{mL}^{-1}$. The anticancer activity of the leaves related to their contents of flavonoids. This study validates the traditional use of plants in the management of cancer.
\end{abstract}

Introduction: Cancer now a day is very widely spread and prevalent disease. Cancer is the third leading cause of death worldwide, preceded by cardiovascular and infectious diseases. It is becoming very common in every age group. It is very serious as its curability is very less due to unawareness for the symptoms and also the proper medication still not available. It is major concern in the health care perspective ${ }^{1}$.

\begin{tabular}{|l|c|}
\hline QUICK RESPONSE CODE & DOI: \\
\hline DOI link: http://dx.doi.org/10.13040/IJPSR.0975-8232.10(7).3295-99 \\
\hline
\end{tabular}

Cervical cancer is one now becoming common in the northeastern region. These are the main perspective to get through this research work in regards to helping the society. Cancer is one of the most life-threatening diseases in which deregulated proliferation of abnormal cells invades and disrupts surrounding tissues. There has been the success of using clinical therapies such as radiation, chemotherapy, immunomodulation, and surgery in the treatment of cancer, but these are limited. So, there is a need for alternative strategies in the management of cancer disease. Natural products can play a significant role as secondary metabolites present in them such as terpenoids, phenolic acids, flavonoids, alkaloids, etc. exhibit antioxidant properties, which is significant in the role of cancer treatment. 
Thus, medicinal plants have become a focal point to improve future health needs against cancer with a lesser harmful effect ${ }^{2}$. The methanol extract of the plant like Mikania micrantha, Allium hookeri, Alpania galanga, Eryngium foetidium was also carried out for anticancer activity studies, which includes the study of cytotoxicity by an MTT assay and cell viability determination by Trypan blue exclusion assay. These two studies will give information on how the plant plays a role in fighting cancer cells. The main principle of cytotoxicity of cells by MTT Assay is that the yellow tetrazolium MTT (3-(4, 5-dimethyl thiazolyl-2)-2, 5-diphenyltetrazolium bromide) is reduced by metabolically active cells, in part by the action of dehydrogenase enzymes, to generate reducing equivalents such as NADH and NADPH. The resulting intracellular purple formazan can be solubilized and by spectrophotometric means ${ }^{3,4,5}$.

\section{MATERIALS AND METHODS:}

Plant Materials: Plants samples such as Mikania micrantha, Allium hookeri, Eryngium foetidium, and Alpinia galangal were collected from Mizoram. The plant specimens were authenticated by Dr. A. A. Mao (Scientist-F \& H) Botanical Survey of India, Shillong. A voucher specimen of these plants has been deposited in the Department of Pharmacy, with Reference no: BSI/ERC/ TECH/2017/589 for future reference. Then samples were subjected for hot methanol extraction. The plant's extract was dried at room temperature until semi-solid or dryness is obtained. The extract was then dissolved in $0.01 \%$ methanol in distilled water and filtered through $0.22 \mu$. Doxorubicin was used as a positive control with different concentration of $1,2,4,8 \mu \mathrm{g} / \mathrm{ml}^{5,6,7}$.

Cell Lines and Culture Medium: Hela (Human cervical cancer) cell line was procured from National Centre for Cell Sciences (NCCS), Pune, India. Stock cells were cultured in Dulbecco modified eagle media (DMEM) supplemented with $10 \%$ inactivated Fetal Bovine Serum (FBS), penicillin $(100 \mathrm{IU} / \mathrm{ml})$, streptomycin $(100 \mu \mathrm{g} / \mathrm{ml})$ and amphotericin B $(5 \mu \mathrm{g} / \mathrm{ml})$ in a humidified atmosphere of $5 \% \mathrm{CO}_{2}$ at $37{ }^{\circ} \mathrm{C}$ until confluent. The cells were dissociated with trypsin solution (0.2\% trypsin, $0.02 \%$ EDTA, $0.05 \%$ glucose in PBS). The stock cultures were grown in $25 \mathrm{~cm}^{2}$ culture flasks, and all experiments were carried out in 96 microtitre plates (Tarsons India Pvt. Ltd., India).

Sterility Test: It was done to check the extract from the contamination. $35 \mathrm{~mm}$ culture disc was plated with Hela in $2 \mathrm{ml}$ of DMEM media and allow the cell to adhere. The crude plant extract was added in the microtitre plate and incubated at $\mathrm{CO}_{2}$ incubator $(5 \%)$ for $24 \mathrm{~h}$.

Cell Viability: The cytotoxic effects of the various plants were investigated using the MTT (Sigma, USA) on HeLa cells. The cells were seeded in 96well plates at a density of $2 \times 10^{4}$ cells per well. After incubation for 20-24 h, the cells with 70 $80 \%$ confluency were treated with the extracts at different concentrations $(5,25,50,100$ and $200 \mu \mathrm{g}$ $\left.\mathrm{mL}^{-1}\right)$ and incubated for $24 \mathrm{~h}$. Then, $20 \mu \mathrm{L}$ of MTT $(5 \mathrm{mg} / \mathrm{mL})$ solution was added to cells per well, and the plate was moved to a cell incubator for another $4 \mathrm{~h}$. The medium was removed, and $150 \mathrm{~mL}$ of DMSO was added to the cells. The plate was gently shaken for 15 min to dissolve the formazan crystals generated by proliferating cells, and the measurement was performed using a Spectramax M2 Microplate Reader (Molecular Diagnostic, Inc.) at a wavelength of $570 \mathrm{~nm}$. Relative viability was calculated taking wells with non-treated cells as $100 \%$ control $^{8,9,10}$.

Test for Cellular Proliferation (MTT Assay Protocol): Seeded the HeLa at $3 \times 10^{5}$ cells/well in a 96 well plate. Cells may be seeded at different densities. At least three wells were left without cells. These wells serve as a control for the minimum absorbance. The plate was incubated overnight at $37{ }^{\circ} \mathrm{C}$ in a humidified incubator, 5\% $\mathrm{CO}_{2}$ for the cancer cells to grow and adhere to the surface. Test compounds were added to the plate. Include replicates for a range of concentrations. Include negative controls (including vehicle control) and positive control.

The final volume will be $100 \mu 1$ per well. The plate was incubated for overnight (or for some other appropriate time) at $37^{\circ} \mathrm{C}$ in a humidified incubator, $5 \% \mathrm{CO}_{2}$. MTT reagent $(20 \mu \mathrm{l} / 100 \mu \mathrm{l}$ per well of the 96well plate) was added. Incubated at $37{ }^{\circ} \mathrm{C}$ for $4 \mathrm{~h}$. 1 volume $(100 \mu \mathrm{l})$ of the stop mix solution was added, and the plate was rocked at room temperature for a minimum of $1 \mathrm{~h}$. 
(Allows time for the formazan precipitate to dissolve). The stop mix solution must be added in a fume hood. A purple color should be visible at this stage and should deepen over the 1-hour incubation period. After the 1-hour incubation, ensure the formazan precipitate is dissolved by pipetting each well up and down until no precipitate is visible.

Read the plate on a plate reader using wavelength at $572 \mathrm{~nm}$. Tabulate results and calculate the \% viability ${ }^{6,7}$.

$\%$ Viability $=$ Mean absorbance of sample $\times 100 /$ Mean absorbance of control

Morphological Staining: To observe the morphological changes of the cells, an inverted phase contrast microscope was used. Cells were inoculated at $3 \times 10^{5}$ cell/well in 24 well microplates and treated mentioned manner. Other culture wells were treated by $\mathrm{H}_{2} \mathrm{O}_{2}(100 \mu \mathrm{m})$ as a positive control of apoptosis and necrosis; respectively, as the negative control, some culture wells were prepared without any treatment. After being cultured for $16 \mathrm{~h}$, the culture media removed, and cells fixed and stained by the standard hematoxylin-eosin method. The prepared samples were photographed at $\times 100$.
Statistical Analysis: One-way analysis of variance (ANOVA), Duncan and Wilcoxon test were used for data analysis. All the results are expressed as the mean $\pm \mathrm{SD}$, and $\mathrm{p}$-values below 0.05 were considered statistically significant.

\section{RESULTS AND DISCUSSION:}

In-vitro Anti-Cancer Activity (MTT Assay): The MTT assay results for $24 \mathrm{~h}$ and $48 \mathrm{~h}$ incubation of crude drug at the concentrations of $5,25,50,100$, and $200 \mu \mathrm{g} / \mathrm{ml}$ showed increased HeLa cell viability as the concentration got diluted.

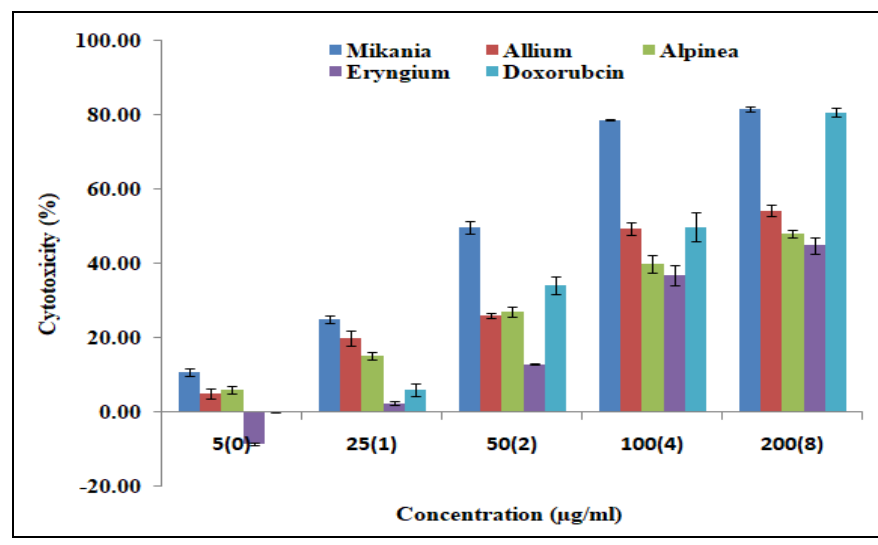

FIG. 1: THE GRAPH REPRESENTS THE PERCENTAGE CELL CYTOTOXICITY OF EXTRACTS AGAINST HELA CELLS. THE BRACKETS INDICATE CONCENTRATION OF DOXORUBICIN

TABLE 1: THE PERCENTAGE CELL VIABILITY OF HELA CELL LINES AGAINST PLANTS EXTRACT

\begin{tabular}{|c|c|c|c|c|c|c|c|c|c|c|}
\hline \multirow{2}{*}{$\begin{array}{c}\text { Conc. } \\
(\mu \mathrm{g} / \mathrm{ml})\end{array}$} & \multicolumn{2}{|c|}{ Doxorubicin } & \multicolumn{2}{|c|}{ Mikania micrantha } & \multicolumn{2}{|c|}{ Allium hookri } & \multicolumn{2}{|c|}{ Alpinia galanga } & \multicolumn{2}{|c|}{ Eryngium foetidium } \\
\hline & Mean & SD & Mean & SD & Mean & SD & Mean & SD & Mean & SD \\
\hline $25(1)$ & 6.07 & 1.61 & 25.07 & 1.17 & 19.94 & 2.00 & 15.19 & 1.08 & 2.50 & 0.52 \\
\hline $100(4)$ & 50.00 & 3.93 & 78.79 & 0.25 & 49.50 & 1.66 & 40.01 & 2.39 & 37.06 & 2.74 \\
\hline $200(8)$ & 80.72 & 1.24 & 81.54 & 0.72 & 54.35 & 1.51 & 48.22 & 1.01 & 44.97 & 2.14 \\
\hline $\mathrm{IC}_{50}$ & 3.31 & & 49.02 & & 138.50 & & 199.70 & & 209.40 & \\
\hline
\end{tabular}

The data present as Mean $\pm \mathrm{SD}, \mathrm{n}=3$; *The brackets indicate the concentration of doxorubicin

Morphological Staining: Morphological study of cell shape changes was performed by direct microscopy, hematoxylin, and eosin staining, using an inverted phase-contrast microscope (400X), it was found that the untreated cells exhibited normal shapes, with clear outline. Although the growth of the methanolic-extract-treated cells was inhibited. The extract treated cells were round; proliferation was inhibited and slowed.
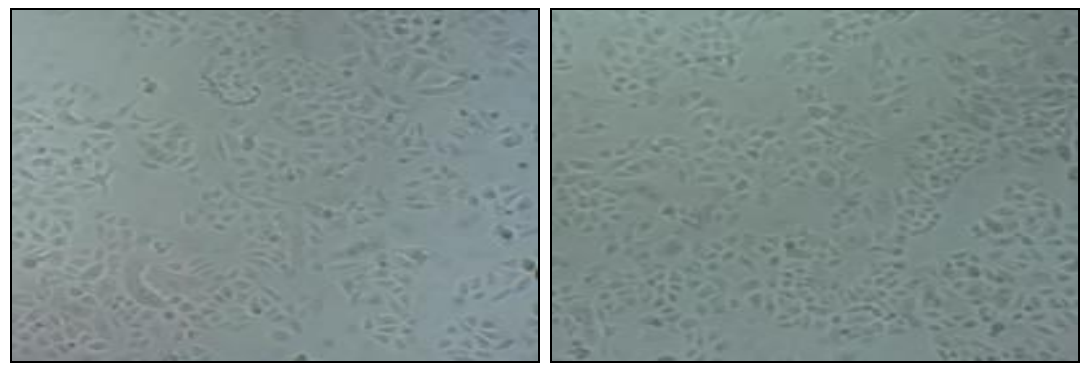

After $48 \mathrm{~h}$ of Treated cells but before the addition of MTT 


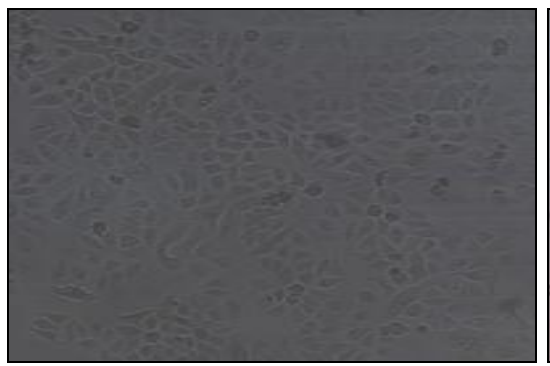

Control

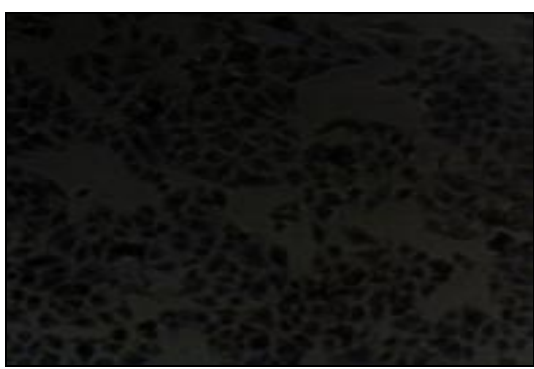

Alpania galangal

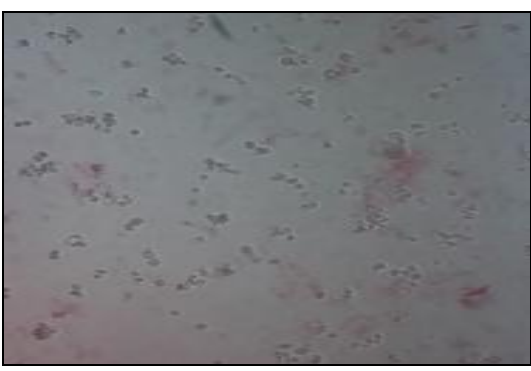

Doxorubicin $(4 \mu \mathrm{g} / \mathrm{ml})$

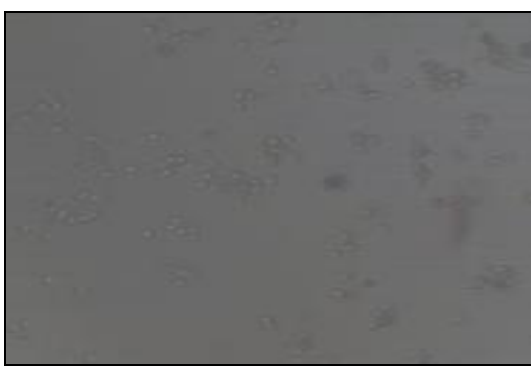

Eryngium foetidium

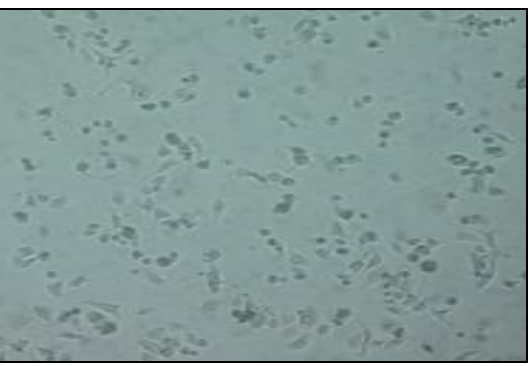

Mikania micrantha

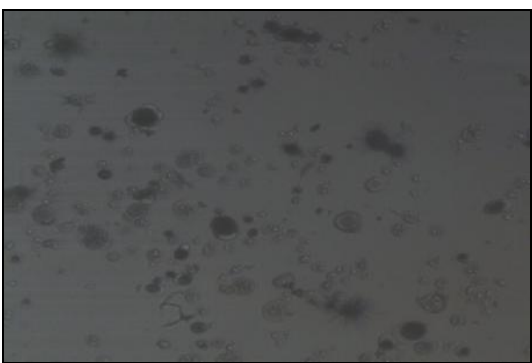

Allium hookeri

After $48 \mathrm{~h}$ of Treated cells incubated with MTT for $3 \mathrm{~h}$

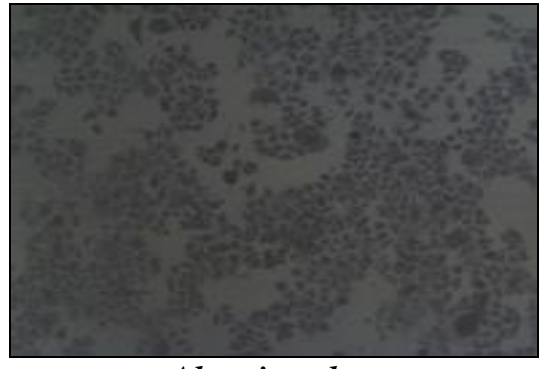

Alpania galanga

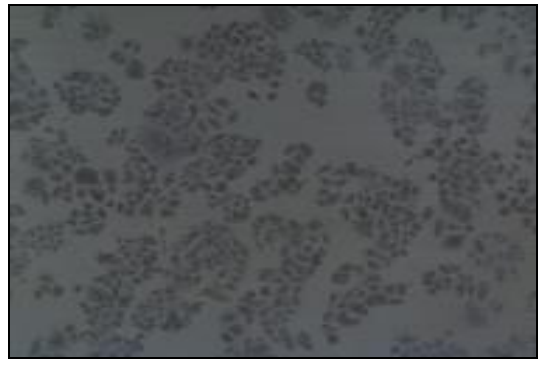

Eryngium foetidium

FIG. 2: REPRESENTS VARIOUS PLANTS EXTRACTS TREATED HELA WITH $100 \mu \mathrm{g} / \mathrm{ml}$. ABOVE LANE 48 h TREATED AND BELOW REPRESENTS $48 \mathrm{~h}$ TREATED FOLLOWED BY INCUBATION WITH MTT. THE PURPLE CRYSTAL FORMATION INDICATED VIABLE CELLS. LESSER PURPLE CRYSTAL FORMED, MORE CELL DEAD ${ }^{3,11,12}$

CONCLUSION: The Cytotoxicity of studied medicinal plants of Mizoram such as Mikania micrantha, Allium hookeri, Eryngium foetidium, and Alpinia galanga exhibited cytotoxicity in an increased manner with increase concentration against HeLa cells. Their $\mathrm{IC}_{50}$ values were 49.02, $138.5,199.7$, and $209.4 \mu \mathrm{g} \mathrm{mL}^{-1}$, respectively. The $\mathrm{IC}_{50}$ of doxorubicin was $3.305 \mu \mathrm{g} \mathrm{mL}^{-1}$.

ACKNOWLEDGEMENT: This work was supported by the Regional Institute of Paramedical and Nursing Sciences. I would like to give special thanks to DBT-Advanced level state biotech hub, Mizoram University for allowing me to carry out this project in their laboratory. The author would like to thank for his technical support to the institute and also thank Ms. S.H. Victoria Devi for her valuable guidance.

\section{CONFLICT OF INTEREST: Nil}

\section{REFERENCES:}

1. Gali K, Ramakrishnan G, Kothai R and Jaykar B: In-vitro anti-cancer activity of methanolic extract of leaves of Argemone Mexicana. International Journal of Pharm Tech Research 2011; 3: 1329-33.

2. Tagne RS, Telefo BP, Nyemb JN, Yemele DM, Njina SN, Goka SMCG, Lienou LL, Kamdje AHN, Moundipa PF and Farooq AD: Anticancer and antioxidant activities of methanol extracts and fractions of some Cameroonian medicinal plants. Asian Pacific J of Tropical Medicine 2014; 7: 442-47.

3. Promkum C, Butryee C, Tuntipopipat S and Kupradinun P: Anticlastogenic effect of Eryngium foetidum L. assessed by erythrocyte micronucleus assay. Asian Pacific Journal of Cancer Prevention 2012; 13: 3343-34.

4. Han LT, Fang Y, Li MM, Yang HB and Huang F: The Antitumor Effects of Triterpenoid Saponins from the Anemone flaccida and the Underlying Mechanism, Evidence-Based Complementary and Alternative Medicine 2013; Article ID 517931: 1-8

5. Mosamann T: Rapid colorimetric assay for cellular growth and survival, application to proliferation and cytotoxicity assay. J Immunol Methods 1983; 65: 55-63.

6. Sakinehsalehi, Zahri S and Razavi SM: Cytotoxic effect of Prangos pabularia extracts on HELA cell line a medicinal 
plant. International Journal of Medical Research \&Health Sciences 2016; 5: 547-52.

7. Kostova I: Synthetic and natural coumarins as cytotoxic agents: Current Medicinal Chemistry-Anti-Cancer Agents 2005; 5(1): 29-46.

8. Plumb JA: Cell sensitivity assays: the MTT assay. Methods Mol Med 2004; 88: 165-9.

9. Denecker G, Vercammen D, Declercq W and Vandenabeele P: Apoptotic and necrotic cell death induced by death domain receptors. Cellular and Molecular Life Sciences CMLS 2001; 58(3): 356-70.
10. Kameshwaran S, Suresh V, Arunachalam G, Kanthlal SK, Mohanraj M: In-vitro \& in-vivo anticancer activity of methanolic extract of Tecoma stans flower. Int Res $\mathrm{J}$ Pharm 2012; 3: 246-51.

11. The Ayurvedic Pharmacopoeia of India, PartI, Volume V, Government of India, Ministry of Health and Family Welfare, Department of Ayush.

12. Saha P, Mazumdar UK and Halder PK: Acute and sub chronic toxicity of C. maxima aerial parts. Int J Res Pharm \& Biomed Sci 2011; 2: 634-38.

\section{How to cite this article:}

Barbhuiya SMAA and Devi SHV: In-vitro comparative anticancer activity study of methanolic extract of traditionally used medicinal plant of Mizoram. Int J Pharm Sci \& Res 2019; 10(7): 3295-99. doi: 10.13040/IJPSR.0975-8232.10(7).3295-99.

All @ 2013 are reserved by International Journal of Pharmaceutical Sciences and Research. This Journal licensed under a Creative Commons Attribution-NonCommercial-ShareAlike 3.0 Unported License.

This article can be downloaded to Android OS based mobile. Scan QR Code using Code/Bar Scanner from your mobile. (Scanners are available on Google Play store) 